Jahangirnagar University J. Biol. Sci. 7(1): 23-34, 2018 (June)

\title{
Screening of protease producing bacteria from tannery wastes of leather processing industries at Hazaribag, Bangladesh
}

\author{
Md. Saimoon Rahman ${ }^{1}$, Md. Rayhan Islam ${ }^{1}$, Omit Kumer Mondol, Mohammad \\ Shahedur Rahman, Farah Sabrin ${ }^{2}$ and Umme Salma Zohora* \\ Department of Biotechnology and Genetic Engineering, Jahangirnagar University, Savar, \\ Dhaka-1342, Bangladesh
}

\begin{abstract}
Protease enzymes are ubiquitous in nature and usually found in all living organisms. The present study was conducted for screening bacteria with the ability to produce extracellular proteases. Attempts were made to isolate protease producing bacterial strains from soil samples of tannery wastes from Hazaribag, Bangladesh and subsequent partial characterization was performed. A number of biochemical assays was performed for presumptive identification of the bacteria. Subsequent molecular identification of bacterial isolates was performed using $16 \mathrm{~S}$ rRNA sequence analysis, which revealed that the isolated bacterium R82 to be Bacillus subtilis. The protease enzyme activity was determined 60.50 $\mathrm{U} / \mathrm{mL}$. Further characterization showed that the enzyme produced from the bacteria was extracellular and alkaline protease in nature. The optimum reaction incubation time, $\mathrm{pH}$ and temperature were found to be $30 \mathrm{~min}, 8.0$ and $50^{\circ} \mathrm{C}$, respectively. Bacterial culture supernatant was used to carry out dehairing of leather $\left(2^{\prime \prime} \times 2^{\prime \prime}\right)$, which was achieved in $24 \mathrm{~h}$. The results showed that isolated bacterial strain could be employed for strain improvement towards commercial production of protease with a promise for dehairing in leather processing industries.
\end{abstract}

Key words: Protease, 16s rRNA sequence, tannery waste.

\section{INTRODUCTION}

From the very beginning of industrialization in Bangladesh, leather-processing industries have been playing a significant role in the country's economy as a means of earning foreign currency. According to the Bangladesh Export Promotion Bureau of statistics, Bangladesh exported leather and leather goods worth $\$ 1.13$ billion in the financial year 2014-15. In Bangladesh, these industries are well established and ranked second in terms of earning foreign exchange (Export statistics 2015). Most of the industries in Bangladesh use chemicals for dehairing and pose a significant threat to environment and ecosystem. Recent estimate showed approx. $60 \times 10^{3}$ tons of raw hides and skins were processed in these industries every year and released nearly 95,000 liters of untreated effluents daily enriched with heavy metals into the open environment, resulting in dead Buriganga river (Rasul et al., 2006). In addition, the effluents also damaged other water resources such as surrounding agriculture and fisheries (Raju et al., 1996).

\footnotetext{
${ }^{1}$ Biotechnology and Genetic Engineering Discipline, Khulna University, Khulna-9208, Bangladesh

${ }^{2}$ Department of Biotechnology and Genetic Engineering, Mawlana Bhashani Science and Technology University, Santosh, Tangail-1902, Bangladesh

*Corresponding author. Email: zohoraus@bgeju.edu.bd
} 
In recent time, enzymatic dehairing showed excellent promise as an environment friendly alternative to the conventional chemical process (Nam et al., 2002). Leather industry makes use of enzymes like protease, lipase that softens fibers; improve quality, and present alternatives to chemical method (Dayanandan et al., 2003). The use of proteolytic enzymes (protease) as an alternative to dehairing skins was investigated in the industries. The proteolytic dehairing involves the cleavage of the cementing substances holding the hair to the skin so that the hair can be removed without destruction (Dutta 1985). Biological methods are being used with relative success in soaking, dehairing, bating and, in part, degreasing in the developed countries. However, enzymes are only used in the bating stages in Bangladesh.

Proteases are produced by a wide range of microorganisms including bacteria, molds and yeasts, actinomycetes etc (Akcana \& Uyar, 2011). In bacteria, this enzyme is produced mainly by a member of strains belonging to genus Bacillus especially, B. licheniformis; $B$. horikoshii, B. sphaericus, B. furmis, B. alcalophilus, B. subtilis (Ellaiah et al., 2011). Bacillus species are the main producers of extracellular proteases, and industrial sectors frequently use B. subtilis for the production of various enzymes (Dubal et al., 2008). Currently, commercially available proteases are not sufficient to meet industrial demands and in many cases, they lose significant activity over the period of shipment from other countries. Hence, there remains a scope of further search for new proteases with novel characteristics for industrial applications from diverse bacterial isolates. Microbes from varied habitats have been explored by the researchers to obtain industrially suitable proteases. The aim of the present study was to screen proteaseproducing bacteria from tannery wastes of leather-processing industries at Hazaribag, Bangladesh and subsequent characterization of the enzyme produced.

\section{MATERIALS AND METHODS}

Isolation of bacterial strains: The soil samples were collected from the tannery waste of East Asia Tannery, Hazaribag near Dhaka city, Bangladesh. The samples were kept in sterilized glass vials for further analysis. For the isolation of bacteria, soil samples were serially diluted and spread on skimmed milk agar plate (SMA). At first, the samples were mixed with sterile $0.85 \% \mathrm{NaCl}$ solution and vortexed. Ten-fold serial dilutions were then carried out. It was followed by spreading $0.1 \mathrm{~mL}$ of each dilution aseptically on SMA plates by a glass spreader. The plates were incubated at $37^{\circ} \mathrm{C}$ for overnight in an incubator (Compact Economic Incubator, 141208-37, Korea). After $24 \mathrm{~h}$ incubation, clear zones were observed and differential growth patterns of bacteria were found in each SMA plate. In this process, a small amount of inoculums from each morphologically different single colony were cultured into LB broth at $37^{\circ} \mathrm{C}$ for overnight.

Comparative proteolytic activity analysis on SMA and skimmed milk solution: First, $1 \mu \mathrm{L}$ of culture was spotted on SMA media plates (4 spots per plate). The plates were then incubated at $37^{\circ} \mathrm{C}$ for $24 \mathrm{~h}$. Bacterial proteolytic activity zone was measured and recorded. Additionally, isolated bacterial strains were cultured in skimmed milk liquid media at $37^{\circ} \mathrm{C}$ for $24 \mathrm{~h}$ under $120 \mathrm{rpm}$. Then, $1 \mathrm{~mL}$ of culture from each strain was 
transferred to a sterile microfuge tube after vortexing. The tubes were centrifuged at $14000 \mathrm{rpm}$ for $15 \mathrm{~min}$ (Eppendorf 5418ZQ115334, Germany) and 5mL of skimmed milk solution $(7.7 \mathrm{mg} / \mathrm{mL})$ was transferred to a test tube followed by addition of $0.2 \mathrm{~mL}$ supernatant. Then the mixture was incubated at $37^{\circ} \mathrm{C}$ for $20 \mathrm{~min}$ at $120 \mathrm{rpm}$. Absorbance was taken at $660 \mathrm{~nm}$ using spectrophotometer (Optizen pop, Mecasys Co., Ltd., Taiwan) at $0 \mathrm{~min}$ and $20 \mathrm{~min}$. Comparative proteolysis was calculated by the differences of absorbance.

Assessment of extracellular activity of enzyme: Isolated bacterial strains were cultured in the procedure described in the previous section and cells were harvested by centrifuging at $14000 \mathrm{rpm}$ for $15 \mathrm{~min}$. The supernatant was separated and $10 \mu \mathrm{L}$ of it was transferred to SMA media with antibiotics (Tetracycline $1.7 \mathrm{mg} / \mathrm{L}$, streptomycin 2.5 $\mathrm{mg} / \mathrm{L}$ ). After $24 \mathrm{~h}$, the activity zones were measured in $\mathrm{mm}$ and recorded.

Identification of potent proteolytic bacterial isolates: A series of conventional biochemical tests were carried out for the presumptive identification of the genus of bacterial strains according to Bergey's Manual of Systematic Bacteriology (Sneath, 1986). The molecular identification was also done by $16 \mathrm{~S}$ rRNA gene sequencing. Two universal primer for 16s rRNA gene amplification were used for the purpose of PCR. The sequence for $27 \mathrm{~F}$ forward primer was AGAGTTTGATCMTGGCTCAG while the reverse primer U1492R was GGTTACCTTGTTACGACTT. The 16s rRNA gene was sequenced using ABI 3700 Genetic Analyzer in the $1^{\text {st }}$ Base Laboratory SdnBhd, Malaysia. The 16s rRNA gene sequences were aligned using BioEdit7.2 software. The sample sequences were analyzed using BLAST-NCBI.

Phylogenetic analysis: The evolutionary history was inferred using the Neighbor-Joining method (Saitou \& Nei, 1987). The bootstrap consensus tree inferred from 1000 replicates was taken to represent the evolutionary history of the taxa analyzed (Dubal et al., 2008). Branches corresponding to partitions reproduced in less than 50\% bootstrap replicates were collapsed. The percentage of replicate trees in which the associated taxa clustered together in the bootstrap test (1000 replicates) were shown next to the branches (Felsenstein, 1985). The evolutionary distances were computed using the Maximum Composite Likelihood method (Tamura et al., 2004) and are in the units of the number of base substitutions per site. The analysis involved 21 nucleotide sequences. All positions containing gaps and missing data were eliminated. There were a total of 1376 positions in the final dataset. Evolutionary analyses were conducted in MEGA7 (Kumar et al., 2016).

Inoculum preparation and submerged fermentation for protease production: For inoculum preparation, $50 \mathrm{~mL}$ of nutrient broth medium was transferred to each of $250 \mathrm{~mL}$ cotton plugged Erlenmeyer flask and sterilized in autoclave (Human Lab Inc., DAC-60, Korea) for $15 \mathrm{~min}$. After cooling at room temperature, $100 \mu \mathrm{L}$ of bacterial cultures was aseptically transferred to each flask. The flasks were loaded on a rotary shaking incubator (VS-1205SW1, Korea) at $150 \mathrm{rpm} 37^{\circ} \mathrm{C}$ for $24 \mathrm{~h}$. Protease production was carried out in sterile basal medium $\left(0.1 \% \mathrm{KH}_{2} \mathrm{PO}_{4}, 0.25 \% \mathrm{Na}_{2} \mathrm{HPO}_{4}, 0.1 \% \mathrm{NaCl}, 0.2 \%\left(\mathrm{NH}_{4}\right)_{2} \mathrm{SO}_{4}\right.$, $0.005 \% \mathrm{MgSO}_{4} .7 \mathrm{H}_{2} \mathrm{O}, 0.005 \% \mathrm{CaCl}_{2}$ ) containing $0.2 \%$ tryptone and $1 \%$ soluble starch. 
The initial $\mathrm{pH}$ of the medium was adjusted to 7.0. Erlenmeyer flasks $(250 \mathrm{~mL})$ containing $50 \mathrm{~mL}$ of medium were inoculated with $100 \mu \mathrm{L}$ of an overnight culture and incubated at $37^{\circ} \mathrm{C}$ in a rotary shaker incubator at $150 \mathrm{rpm}$ for $48 \mathrm{~h}$. After incubation, fermented broth was centrifuged at $4^{\circ} \mathrm{C}, 8000 \mathrm{rpm}$ for $15 \mathrm{~min}$ in a cooling centrifuge (Digisystem Laboratory Instruments Inc., DSC-200T, Taiwan). Supernatant was collected and preserved or used for enzyme assay.

Partial characterization of protease activity: To determine the proteolytic activity of the isolated enzyme, the method outlined in Sigma's Universal Protease Activity Assay was followed (Cupp, 2008). To determine the effect of incubation time on protease activity, different incubation times $(5,10,20,30,40,50,60,70,80,90 \mathrm{~min})$ were used. Casein was used as the substrate and was dissolved in Potassium Phosphate buffer at $\mathrm{pH}$ 7.5. Different buffer systems with different $\mathrm{pH}$ were used to determine the effect of $\mathrm{pH}$ on protease activity. Casein was dissolved in different buffer solution and the enzyme assay was carried out within the $\mathrm{pH}$ ranging from 6.0-10.0. The buffer systems were used at $0.02 \mathrm{M}$ concentration. For the determination of the effect of temperature, the reaction medium was incubated at various temperatures and the protease activity was determined. For this purpose the reaction system was incubated at ranging from $30^{\circ} \mathrm{C}-90^{\circ} \mathrm{C}$ with $10^{\circ} \mathrm{C}$ intervals

Assessment of dehairing activity of protease on hide: For dehairing studies, the bacterial culture was grown in protease producing broth at $37^{\circ} \mathrm{C}$ for around $24 \mathrm{~h}$. Then it was centrifuged at $6000 \mathrm{rpm}$ for $20 \mathrm{~min}$. The cell free supernatant was added on detergent washed goat skin $\left(2^{\prime \prime} \mathrm{X} 2^{\prime \prime}\right)$ to observed enzymatic dehairing capability of the bacterial strain tested. Sodium azide $(0.02 \%)$ was used to prevent opportunistic growth of microorganisms.

\section{RESULTS AND DISCUSSION}

Isolation of bacterial strains and primary screening of protease producer: Four bacterial isolates were found to show proteolytic activity in the initial screening on SMA plate. The isolates were designated as R82, R122, R31 and R71, respectively (Fig. 1). The comparison of proteolytic activity for the isolates was demonstrated on SMA and clear zone was observed (Table 1).

Table 1. Comparative analysis of proteolytic activity of the bacterial isolates under investigation

\begin{tabular}{cc}
\hline Bacterial Strain & Zone of Clearance $(\mathrm{mm})$ \\
\hline R82 & 19.28 \\
R122 & 17.03 \\
R31 & 19.13 \\
R71 & 10.75 \\
\hline
\end{tabular}

Oliveira et al. found SMA hydrolysis zones ranged from 2.5-6.1 mm (Oliveira et al., 2016) while Barros et al. observed clearance zones ranging from 2.5 to $10.0 \mathrm{~mm}$ for $10 \mathrm{~B}$. 
subtilis strains grown in SMA plates at $30^{\circ} \mathrm{C}$ for $24 \mathrm{~h}$ (Barros et al., 2013). Singh et al. reported that among 70 proteolytic bacteria isolated from soil, $40 \%$ were considered as good protease producers, exhibiting clearance zones higher than $3 \mathrm{~mm}$ on milk agar plates incubated for $20-30 \mathrm{~h}$ at $37^{\circ} \mathrm{C}$ (Singh et al., 2010). In case of crude enzyme preparation, skimmed milk was used as substrate to evaluate the proteolytic activity and the change in absorbance was found over time. In all cases, the absorbance decreased over time indicating the proteolysis of skimmed milk. However, the absorbance varied respective of bacterial isolates (Table 2). Comparing proteolysis using liquid skimmed milk is novel in that sense; it has not been used for similar work so far. It is easy and faster than spot plating method. Bacterial isolate R82 showed both the highest zone of clearance and difference in absorbance (Table 1 and Table 2).
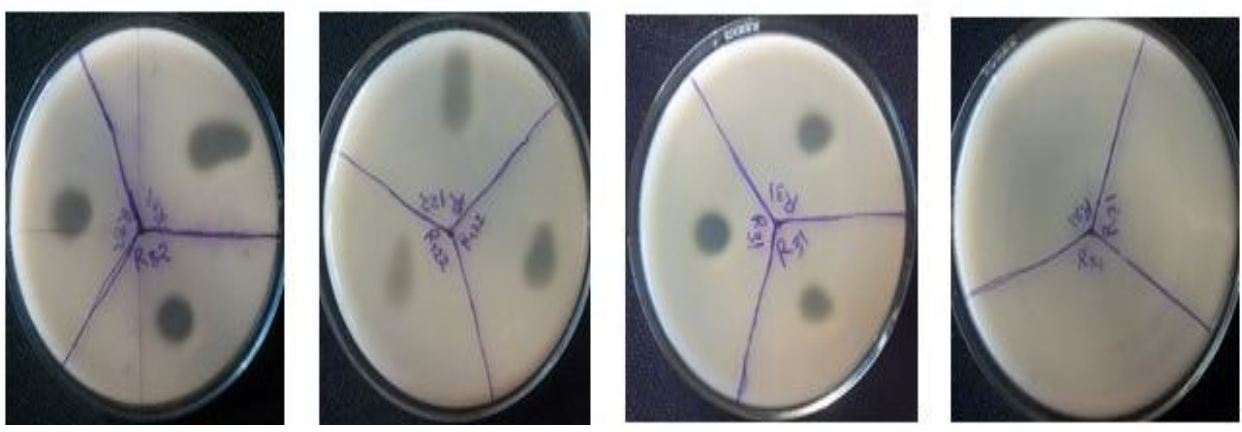

Fig. 1. Isolation of different proteolytic bacterial strains including R82 obtained from tannery wastes Hazaribagh on SMA plate. $10 \square \mathrm{L}$ of culture supernatant was transferred to SMA with $1.7 \mathrm{mg} / \mathrm{L}$ of tetracycline and of $2.5 \mathrm{mg} / \mathrm{L}$ streptomycin and activity zones were measured

Table 2. Comparative analysis of proteolysis of skimmed milk by enzyme

\begin{tabular}{c|c|c|c}
\hline Bacterial Strain & $\mathrm{A}_{660 \mathrm{~nm}}(0 \mathrm{~min})$ & $\mathrm{A}_{660 \mathrm{~nm}}(20 \mathrm{~min})$ & Difference of $\mathrm{A}_{660 \mathrm{~nm}}$ \\
\hline R82 & 1.062 & 0.602 & 0.46 \\
R122 & 1.120 & 0.928 & 0.192 \\
R31 & 1.062 & 1.003 & 0.059 \\
R71 & 1.068 & 0.690 & 0.378 \\
\hline
\end{tabular}

Assessment of extracellular activity of enzyme: Among four isolates, R82 isolate was found to be the best producer of extracellular enzyme as it was able to produce the highest diameter for clear zone (Table 3). Therefore, R82 was selected for further biochemical studies and subsequent molecular identification. Sayem et al. carried out similar experiments in which they showed that microbes were able to degrade skimmed milk on agar plates (Sayem et al., 2006). They reported if antibiotics were added to the SMA medium, which prevented microbial growth and eventually contributed to accuracy. The main reason for using this technique is to enhance accuracy of the overall procedure. 
Thus, it can be concluded from both of the techniques the isolate R82 is the most promising one and the produced enzyme is extracellular.

Table 3. Extracellular activity of the enzyme produced by the bacterial isolates under investigation

\begin{tabular}{c|c|c}
\hline Bacterial Strain & $\begin{array}{c}\text { Clear Zone Diameter }(\mathrm{mm}) \\
(\text { Mean } \pm \text { SD) }\end{array}$ & Comment \\
\hline R82 & $10.58 \pm 0.42$ & Clear \\
R122 & $10.17 \pm 0.85$ & Not Clear \\
R31 & $10.0 \pm 0.82$ & Clear \\
R71 & 0 & No Zone \\
\hline
\end{tabular}

Biochemical and molecular identification of selected isolates: The biochemical identification of the selected isolate was performed according to Bergey's manual of systematic bacteriology (Sneath, 1986) and the isolate was presumptively identified as Bacillus sp. The biochemical test results are presented in Table 4. 16S rRNA gene amplification and sequencing was reported as means of identifying as well as characterizing Bacillus sp (Gomma et al., 2007). The use of molecular techniques along with the conventional methods, adds more precision and accuracy to the phylogenic identification and the true reflection of microbial diversity. According to phylogenetic analysis of nucleotide sequences on the basis of 16s rRNA by BLAST revealed most closely to that the isolate was found to be B. subtilis (Fig. 2). Sundararajan et al. isolated the sample from soil and after 16S rRNA sequencing and phylogenetic tree analysis were carried to characterize the isolates strain VITSN04 and confirmed as B. cereus (Sundararajan et al., 2011). Zambare et al. isolated an organism from vermicompost pit soil and concluded that as Pseudomonas aeruginosa on the basis of its morphological and physiological characteristics, biochemical tests, API system and 16S rRNA sequencing (Zambare et al., 2011). Ates et al. isolated halotolerant bacterial strain from Van Lake in Turkey and morphological, physiological and 16S rRNA gene sequence analysis confirmed it as B. licheniformis strain BA17 (Ates et al., 2007).

Table 4. Morphological and biochemical parameter of $\mathbf{R 8 2}$ isolate

\begin{tabular}{lc}
\hline Name of the test & R82 \\
\hline Gram reaction & + \\
Shape of the cell & Rod \\
Catalase /Gelatin /Starch hydrolysis / Voges-Proskauer/ Nitrate reduction/10\% NaCl & + \\
Methyl Red / Oxidase / Indole / Growth on MacConkey agar & - \\
Carbohydrate fermentation test (Acid production) & + \\
D-Glucose & + \\
D-Fructose & + \\
Sucrose & - \\
Mannitol & - \\
Maltose & \\
Carbohydrate fermentation test (Gas production) & - \\
D-Glucose/ D-Fructose/ Sucrose/ Mannitol/ Maltose &
\end{tabular}




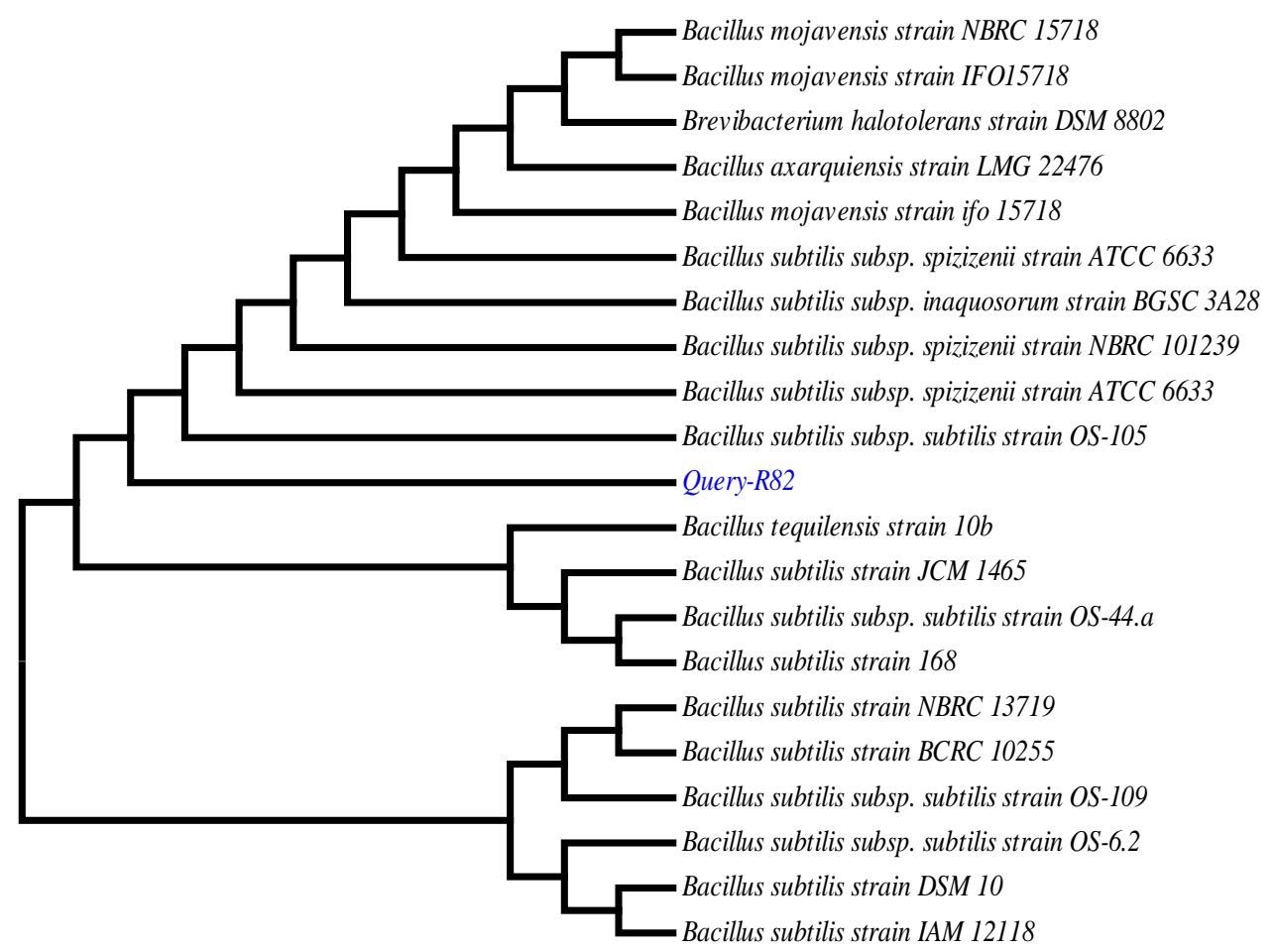

Fig. 2. Phylogenetic analysis of isolate R82. The evolutionary distances were determined using maximum composite likelihood method using MEGA7 software

Partial characterization of protease activity: Proteolytic activity was assayed by Sigma's universal protease activity assay (Cupp, 2008). In the assay, one unit of protease activity is defined as the amount of enzyme required to liberate $1.0 \mu \mathrm{g}$ of tyrosine per min per $\mathrm{mL}$ under the standard assay conditions. In this investigation, the proteolytic activity was found as $60.50 \mathrm{U} / \mathrm{mL}$ for the bacterial strain. However, Verma \& Baiswar (2013) reported maximum protease activity $410 \mathrm{U} / \mathrm{mL}$ for the $B$. cereus under optimum condition (Verma, 2013). Oliveira et al. reported higher protease production as a function of cultivation time (192 U/mL) using Bacillus sp (Oliveira et al., 2016). The variation of the activity could be attributed to the culture condition or the protease assay condition under investigation as the optimization of the tests was not carried out. The maximum activity for the extracellular enzyme produced by the bacterial strain was observed at 30min, which was recorded as the highest (Fig. 3). However, activity appeared to increase within 5-30 min period and decreased gradually after this period if the incubation was further extended.

The $\mathrm{pH}$ of the reaction media affects the protease activity. The enzyme exhibited high activity in alkaline conditions with the optimal pH 8.0 (Fig. 4) and above this $\mathrm{pH}$, the activity started to decline because probably the isolated protease was alakaline in nature. However, its optimum $\mathrm{pH}$ was in good agreement with previous reports (Rozs et al., 
2001). Most proteases were found to show maximum activity in neutral to alkaline conditions, from $\mathrm{pH} 7.0$ to $\mathrm{pH}$ 9.5. For example, optimum the activity of protease from Mycobacterium KR10 was reported to be at pH 7.0 (Thys \& Brandelli, 2006), B. pumilus FH9 at pH 8.0 (Refai et al., 2005), Fervidobacterium islandicum AW-1 at pH 9.0 (Nam et al., 2002).

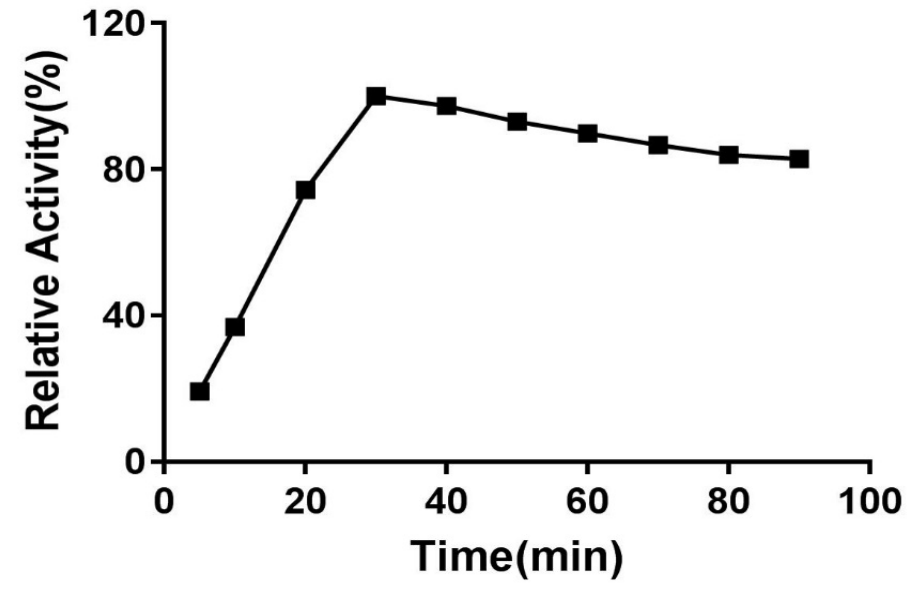

Fig. 3. Effect of incubation time on protease activity of $\mathbf{R 8 2}$ at different incubation times (5, $10,20,30,40,50,60,70,80$ and $90 \mathrm{~min}$ ) using Sigma's universal protease activity assay (UPAA) protocol

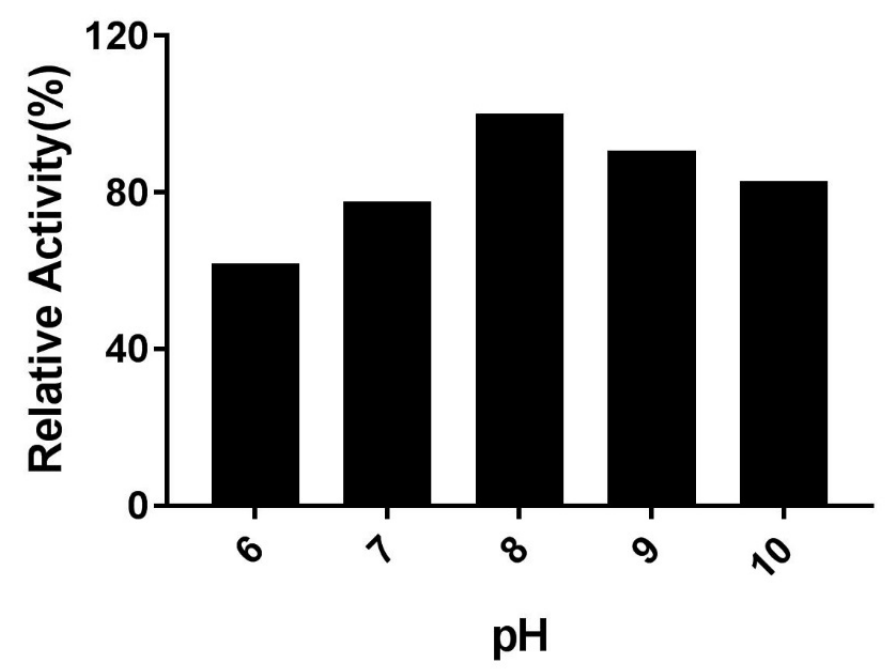

Fig. 4. Effect of $\mathrm{pH}$ on protease activity of $\mathrm{R82}$ determined using casein as a substrate 
The activity of the enzyme was measured over a range of temperature $30^{\circ} \mathrm{C}$ to $90^{\circ} \mathrm{C}$ and shown in Fig. 5. The enzyme activity was found to be increasing with temperature. There was a significant increase in enzyme activity between $30^{\circ} \mathrm{C}$ to $50^{\circ} \mathrm{C}$. The enzyme seemed to be more active at $50^{\circ} \mathrm{C}$ and its activity declined as the temperature increased beyond $50^{\circ} \mathrm{C}$ probably the enzyme was moderately thermophilic. Abusham et al. (2009) reported an alkaline protease of $B$. subtilis strain $\mathrm{R}$ having $100 \%$ stability between $35-55^{\circ} \mathrm{C}$ (Abusham et al., 2009). At $80^{\circ} \mathrm{C}$, the enzyme showed lower activity. This suggests that the enzyme might be a moderately thermo stable enzyme. Most proteases possessed an activity optimum in the range of $30-80^{\circ} \mathrm{C}$. As for example, protease from $B$. pseudofirmus AL-89 was of $60 \sim 70^{\circ} \mathrm{C}$ (Gessesse et al., 2003 ) while a few showed exceptionally high temperature optimum of $100^{\circ} \mathrm{C}$ (Nam et al., 2002).

Table 5. Dehairing ability of $B$. subtilis protease with other bacterial protease ${ }^{(\text {Riffel } \text { et al., 2003) }}$

\begin{tabular}{lcc}
\hline \multicolumn{1}{c|}{ Bacterial strains } & $\begin{array}{c}\text { Incubation time for } \\
\text { Dehairing }\end{array}$ & Change in color of leather \\
\hline $\begin{array}{l}\text { Bacillus subtilis } \text { (Strain under } \\
\text { investigation) }\end{array}$ & $24 \mathrm{~h}$ & no change \\
Vibrio sp $\mathrm{kr} 2$ & $24 \mathrm{~h}$ & no change \\
Flavobacteriumsp $\mathrm{kr} 6$ & $24 \mathrm{~h}$ & no change \\
Bacillus sp $\mathrm{kr} 10$ & $24 \mathrm{~h}$ & no change \\
\hline
\end{tabular}

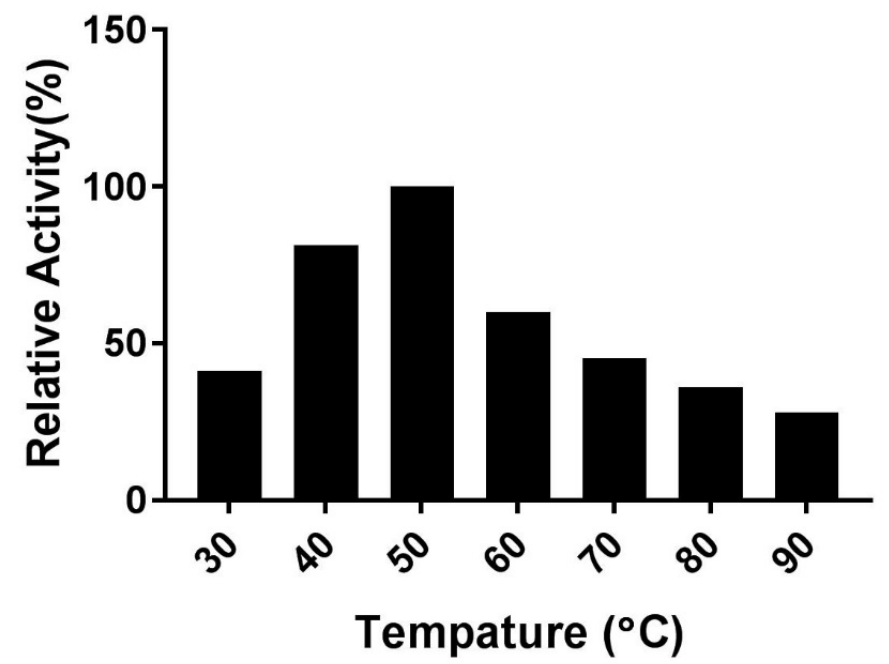

Fig. 5. Effect of temperature on protease activity of R82. The reaction medium containing casein in potassium phosphate buffer of $\mathrm{pH} 7.5$ was incubated at different temperatures and protease activity was determined by UPAA protocol 
Assessment of dehairing activity of protease on hide: Goat skin (2"X2") sample was soaked in prepared crude enzyme filtrate obtained from the selected isolate for a day at room temperature. No color alteration was observed. When hairs were pulled with a forceps, they were very easily removed from hide after enzyme treatment (Fig. 6). Incubation of the protease with skin for dehairing showed that after 24-48 $\mathrm{h}$ incubation of crude enzymes with goat skin hair was removed very easily compared to the control (Riffel et al., 2003). In control, hair loosening was not observed, even by the mechanical action of a forceps. Therefore, the crude protease enzyme preparation showed the capability of dehairing from the hide. The bacterial strain producing the crude enzyme was compared with three different reference bacterial strains (Table 5) and it was found that protease from the strain under investigation produced similar results over same period of incubation without any visible color change of the leather.
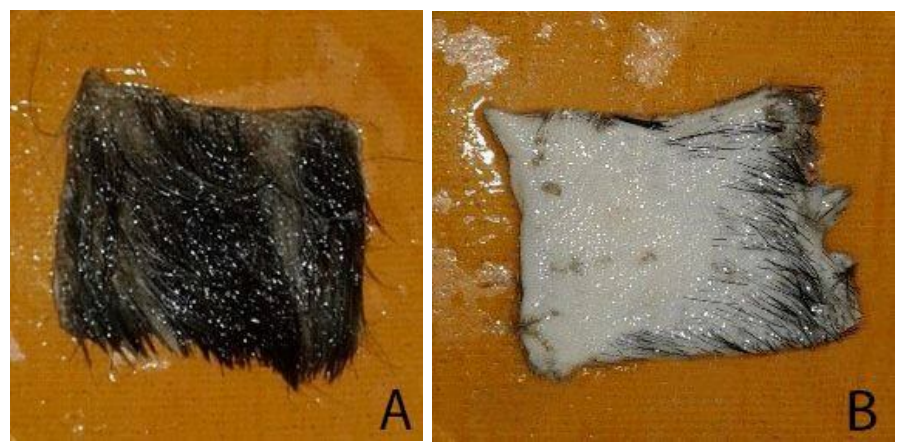

Fig. 6. Dehairing activity of protease at room temperature after $24 \mathrm{~h}$ in water on goat skin (A) control-goat skin incubated at room temperature without protease, (B) Dehaired goat skin with protease from $\mathbf{R 8 2}$

We have identified protease producing bacterium $B$. subtilis from leather processing industrial area of Hazaribag, Dhaka, Bangladesh. The incubation time, $\mathrm{pH}$, temperature for protease production was determined as $30 \mathrm{~min}, 8.0$ and $50^{\circ} \mathrm{C}$, respectively. As the enzyme shows best activity in $\mathrm{pH} 8$ and temp. $50^{\circ} \mathrm{C}$, it can be assumed that it is an alkaline and moderately thermophilic protease enzyme. Dehairing of goat skin was achieved after $24 \mathrm{~h}$ of incubation and found to be capable of dehairing goat skins at almost commercial level. However, further studies are required to use this enzyme to apply commercially.

\section{REFERENCES}

Ateş, Ö., Oner, E.T., Arikan, B., Denizci, A.A. and Kazan, D. 2007. Isolation and identification of alkaline protease producer halotolerant Bacillus licheniformis strain BA17. Annals of microbiology. 57(3):369-75.

Abusham, R.A., Rahman, R,N, Salleh, A,B, and Basri, M. 2009. Optimization of physical factors affecting the production of thermo-stable organic solvent-tolerant protease from a newly isolated halo tolerant Bacillus subtilis strain Rand. Microbial Cell Factories. 8(1):20. 
Akcan, N. and Uyar, F. 2011. Production of extracellular alkaline protease from Bacillus subtilis RSKK96 with solid state fermentation. EurAsian Journal of BioSciences. 5:64-72.

Barros, F.F., Simiqueli, A.P., de Andrade, C.J. and Pastore, G.M. 2013. Production of enzymes from agroindustrial wastes by biosurfactant-producing strains of Bacillus subtilis. Biotechnology research international..

Cupp-Enyard, C. 2008. Sigma's non-specific protease activity assay-casein as a substrate. Journal of Visualized Experiments. 17(19):899.

Dutta, S,S. 1985. An introduction to the principles of leather manufacture. Indian Leather Technologists' Association.

Dayanandan, A., Kanagaraj. J., Sounderraj. L., Govindaraju. R. and Rajkumar. GS. 2003. Application of an alkaline protease in leather processing: an ecofriendly approach. Journal of Cleaner Production. 11(5):533-36.

Dubal, S,A., Tilkari, Y.P., Momin, S.A. and Borkar, I.V. 2008. Biotechnological routes in flavour industries. Advanced Biotech. 20-31.

Ellaiah, P., Srinivasulu, B. and Adinarayana, K. 2002. A review on microbial alkaline proteases. Journal of Scientific \& Industrial Research.61: 690-04.

Export Promotion Bureau (EPB). 2015. Export Statistics. http://www.epb.gov.bd/

Felsenstein, J. 1985. Confidence limits on phylogenies: an approach using the bootstrap. Evolution. 1:783-91.

Gessesse, A., Hatti-Kaul, R., Gashe, B.A. and Mattiasson, B.O. 2003. Novel alkaline proteases from alkaliphilic bacteria grown on chicken feather. Enzyme and Microbial Technology. 32(5):519-24.

Gomma, O.M. and Momtaz, O.A. 2007. 16s rDNA characterization of a Bacillus isolate and tolerance profile after subsequent subculturing. Arab Journal of Biotechnology. 10(1): 107-16.

Islam, M.R., Mondol, O.K., Rahman, M.S., Billah, M.M., Rahman, M.S. and Zohora, U.S. 2016. Screening of $\alpha$-amylase producing bacteria from tannery wastes of Hazaribag, Bangladesh. Jahangirnagar University J. Biol. Sci. 5(2): 1-10

Kumar, S., Stecher, G. and Tamura, K. 2016. MEGA7: Molecular Evolutionary Genetics Analysis version 7.0 for bigger datasets. Molecular Biology and Evolution. 33(7): 1870-74.

Nam, G.W., Lee, D.W., Lee, H.S., Lee, N.J., Kim, B.C., Choe, E.A., Hwang, J.K., Suhartono, M.T. and Pyun, Y.R. 2002. Native-feather degradation by Fervidobacterium islandicum AW-1, a newly isolated keratinase-producing thermophilic anaerobe. Archives of Microbiology. 178(6):538-47.

Oliveira, C.T., Pellenz, L., Pereira, J.Q., Brandelli, A. and Daroit, D.J. 2016. Screening of bacteria for protease production and feather degradation. Waste and Biomass Valorization. 7(3):447-53.

Raju, A.A., Chandrababu, N.K., Samivelu, N., Rose, C. and Rao, N.M. 1996. Eco-friendly enzymatic dehairing using extracellular proteases from a Bacillus species isolate. American Leather Chemists Association. 91:115-19.

Rozs, M., Manczinger, L., Vágvölgyi, C. and Kevei, F. 2001. Secretion of a trypsin-like thiol protease by a new keratinolytic strain of Bacillus licheniformis. FEMS Microbiology Letters. 205 (2):221-24.

Riffel, A., Ortolan, S. and Brandelli, A. 2003. Dehairing activity of extracellular proteases produced by keratinolytic bacteria. Journal of Chemical Technology and Biotechnology. 78(8):855-59.

Refai, H.A., AbdelNaby, M.A., Gaballa, A., El-Araby, M.H. and Fattah, A.A. 2005. Improvement of the newly isolated Bacillus pumilus FH9 keratinolytic activity. Process Biochemistry. 40(7):2325-32. 
Rasul, M.G., Faisal, I. and Khan, M.M. 2006. Environmental pollution generated from process industries in Bangladesh. International Journal of Environment and Pollution. 28(12):144-61.

Sneath, P.H. 1986. Endospore-forming Gram-positive rods and cocci. Bergey's manual of Systematic Bacteriology.2:1104-39.

Saitou, N. and Nei, M. 1987. The neighbor-joining method: a new method for reconstructing phylogenetic trees. Molecular Biology and Evolution. 4(4):406-25.

Sayem, S.A., Alam, M.J. and Hoq, M.M. 2006. Effect of temperature, pH and metal ions on the activity and stability of alkaline protease from novel Bacillus licheniformis MZK03. Proceedings Pakistan Academy of Sciences. 43(4):257.

Singh, S.K., Tripathi, V.R., Jain, R.K., Vikram, S. and Garg, S.K. 2010. An antibiotic, heavy metal resistant and halotolerant Bacillus cereus SIU1 and its thermoalkaline protease. Microbial Cell Factories. 9(1):59.

Sundararajan, S., Kannan, C.N. and Chittibabu, S. 2011. Alkaline protease from Bacillus cereus VITSN04: Potential application as a dehairing agent. Journal of bioscience and bioengineering. 111(2):128-33.

Tamura, K., Nei, M. and Kumar, S. 2004. Prospects for inferring very large phylogenies by using the neighbor-joining method. Proceedings of the National Academy of Sciences of the United States of America. 101(30):11030-35.

Thys, R.C. and Brandelli, A. 2006. Purification and properties of a keratinolytic metalloprotease from Microbacterium sp. Journal of Applied Microbiology.101 (6):1259-68.

Verma, T. and Baiswar, V. 2013. Isolation and Characterization of Extracellular Thermoalkaline protease producing Bacillus cereus isolated from tannery effluent. International Journal of Engineering Science. 2:23-29.

Zambare, V., Nilegaonkar, S. and Kanekar, P. 2011. A novel extracellular protease from Pseudomonas aeruginosa MCM B-327: enzyme production and its partial characterization. New biotechnology. 28(2):173-81. 